\title{
Recovery of Residual Light Oil from Waterflooded Reservoirs Using Horizontal Wells - Insitu Combustion Process
}

\author{
Greaves M., Ben Rahil M.
}

University of Bath, U. K.

Copyright 1896 , Stering Committoe of the European IOR - Symposium.

This paper was presented at the Oth. European IOR - Symposium in Vienna. Austria, May 16 - 17, 1995

This paper was elected for presentetion by the Steering Committee, following review of information epntained in an abstract

submitted by the author(s). The paper, as presented has not been reviewed by the steoring Committoo.

\begin{abstract}
Preliminary 3D tests have been performed to physically simulate light oil in situ combustion (ISC) under waterflooded conditions. The experiments were carried out in a rectangular combustion cell using light Forties crude oil. A VIHP: vertical injector-horizontal producer well arrangement was used in line drive and also pattem drive. Two levels of residual oil-water saturation were investigated, $60-35 \%$ and $50-45 \%$, using air and oxygen injection under dry forward combustion.
\end{abstract}

Generally high combustion zone temperatures and reasonably high combustion front velocities were sustained using line drive. The horizontal producer well in line drive generally conferred a good level of stability on the combustion front propagation, with only a small tendency overall towards gas override. This effect appeared to be controlled to a certain extent by the draw-down action of the horizontal well, nearer to the production end of the cell. In pattern drive, the propagation and extent of the combustion front was much less vigorous. Maximum oil recovery using line drive (67\% OOIP) coincided with the highest initial residual oil saturation $\left(\mathrm{S}_{\mathrm{oi}}=60 \%\right.$ ), reducing to $51 \%$ at $\mathrm{S}_{\mathrm{oi}}=50 \%$. Oxygen injection gave the lowest oil recovery at $46 \%$ OOIP.

Although oxygen utilisation generally remained in a low range and produced oxygen levels were commensurately fairly high, low temperature oxidation (LTO) reaction was apparently only significant during the pattern drive and oxygen (line drive) tests. Measured horizontal and vertical temperature profiles in the sandpack indicate there is a substantial steam-combustion drive mechanism occurring, under otherwise dry combustion conditions. The volumetric sweep efficiency of this zone appears to reach up to nearly 100 per cent for all cases.

\section{INTRODUCTION}

A recent review of improved oil recovery (IOR) strategy for the UKCS [1] identified gas injection and horizontal and extended reach well technology as having the highest IOR potential, estimated at $3800 \mathrm{MMBOE}$. Hot water. steam and in situ combustion processes were aligned with the recovery of so-called 'viscous' oil, or medium heavy crude oil of API gravity around 20 to 25 . The incremental oil from all IOR techniques was estimated to be $6 \%$ (probable) and up to $11 \%$ (probable plus potential) at an oil price of $\$ 18$ per barrel. A further $46 \%$ of the oil was categorised as unrecoverable. Experience over the last decade has shown that assumptions underlying such an analysis tend to be vulnerable to radical shifts in oil price factors and political exigency. There is, however, some opinion that the current surplus in oil supply is being eroded by increasing demand in the markets. 
The key technological element in IOR strategy, over the medium to long term, will be AEORP's, or advanced EOR processes, with the potential to maximise investment by recovering a high fraction of the trapped residual oil. Air injection has been proposed as a process for the recovery of residual light oil from deep, high pressure reservoirs [2]. Energy generated by the in situ combustion reactions is translated into a series of successiveinteracting sub-processes, involving convective gas, distillation, steam and hot water drives, plus miscible drive via $\mathrm{CO}_{2}$ and condensation of light ends. Thermal transport is a primary process mechanism, especially via the steam produced in $s i t u$, at a partial pressure perhaps one-half the total reservoir pressure. The conductive heat transfer mechanism is absent in all other non-thermal recovery processes, yet at sufficiently high temperatures it can mobilise otherwise noncontactable oil. The IOR or EOR efficiency of air injection is, therefore, potentially very high.

Although there have been a significant number of combustion tube studies conducted on light oil [34], which have identified a number of the main characteristics of the process, none has investigated behaviour in a three-dimensional geometry. This paper presents some preliminary results of an air injection/in silu combustion process which utilises a horizontal production well to recover residual light oil.

\section{EXPERIMENTAL}

The three-dimensional (3D) combustion cell was a rectangular, thin-walled stainless steel box, designed for a maximum operating pressure of $500 \mathrm{kPa}$. In practice, the operating pressure was limited to $270 \mathrm{kPa}$. The rectangular cell. which was constructed of 316 stainless steel. $4 \mathrm{~mm}$ thick. was $0.4 \mathrm{~m}$ square by $0.10 \mathrm{~m}$ deep. A VIHP (vertical injector-horizontal producer) well configuration was used, arranged with the horizontal producer either in direct line drive (at right angles to the vertical injector), or in pattern drive (parallel to the production end of the cell, opposite to the vertical injector-inlet end). Both injection and production wells were constructed from $6.4 \mathrm{~mm}$ O.D. stainless steel tubing, with the horizontal section perforated with $1.6 \mathrm{~mm}$ holes on a $0.6 \mathrm{~cm}$ spacing. A 100 B.S. gauge stainless steel mesh was weided onto the tubing to prevent fine sand or clay particles from blocking the tube.

The principal means of observing the internal state of the process was by means of sixty thermocouples arranged on three horizontal levels - TOP, MIDDLE and BOTTOM. These were located, respectively, $0.03 \mathrm{~m}, 0.06 \mathrm{~m}$ and $0.09 \mathrm{~m}$ from the top surface of the combustion cell. All temperature measurements were logged automatically by an Analog Devices Macsym II computer. Figure $I$ shows a flowsheet schematic of the combustion cell system.

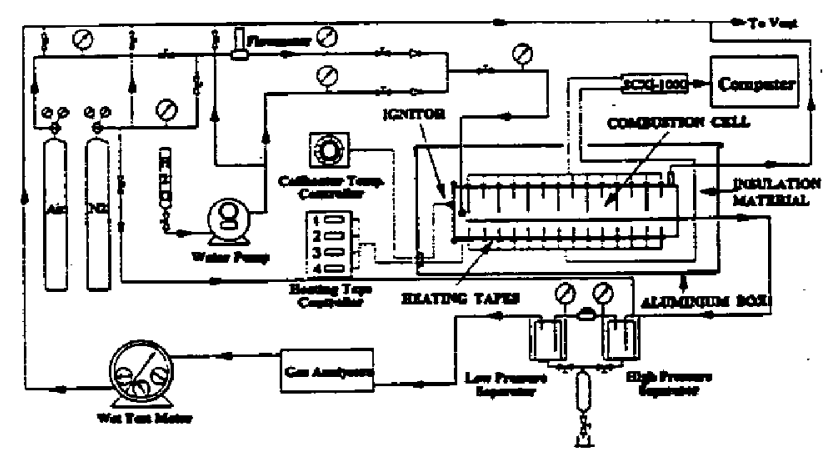

Figure 1

3-D Combustion Cell System

The initial sandpack conditions for each test and the injected oxidant gas condition are listed in Table 1. Further details of the equipment and experimental procedures are given in the thesis by Ben Rahil [6].

Table 1

Sandpack Properties and Initial Combustion Test Conditions

\begin{tabular}{|l|c|c|c|c|}
\hline Run No. & 1 & 2 & 3 & 4 \\
\hline Porosiry (\%) & 35 & 35 & 35 & 35 \\
\hline $\mathrm{S}_{\mathrm{ij}}(\%)$ & 60 & 50 & 60 & 50 \\
\hline $\mathrm{S}_{\mathrm{ut}}(\%)$ & 35 & 45 & 35 & 45 \\
\hline Injected gas & air & air & air & $99 \%$ axygen \\
\hline $\begin{array}{l}\text { Injected oxygen nlux } \\
\left(\mathrm{m}^{3} / \mathrm{h} \mathrm{m} \mathrm{m}^{2}\right)\end{array}$ & 3.15 & 3.15 & 3.15 & 6 \\
\hline
\end{tabular}

\section{RESULTS AND DISCUSSION}

A summary of the overall results for the four light oil in situ combustion tests is given in Table 2.

The maximum combustion peak temperatures vary from a low of $460^{\circ} \mathrm{C}$ (pattern drive) up $10550^{\circ} \mathrm{C}$ (line drive), indicating that there was a fairly vigorous burn condition in each of the tests. However, the temperature trend was typical of dry combustion experiments, in that the combustion peak temperature tended to decline as combustion time increased. The difference in maximum combustion peak temperature is only $40^{\circ} \mathrm{C}$ for the line drive arrangement and the highest temperature was achieved with $99 \%$ oxygen, at almost twice the oxygen flux used in the other 
tests. This latter test also gave the highest combustion front velocity of $0.11 \mathrm{~m} / \mathrm{h}$, before the $\mathrm{CO}_{2}$ concentration in the production gas declined sharply.

Table 2

\section{Insitu Combustion Test Results}

\begin{tabular}{|c|c|c|c|c|}
\hline Run No. & $\begin{array}{c}1 \\
\text { (line } \\
\text { drive) } \\
\end{array}$ & ${ }^{2}{ }^{2}$ & $\begin{array}{c}3 \\
\text { (pattern } \\
\text { drive) } \\
\end{array}$ & $\begin{array}{l}+ \\
\text { (line } \\
\text { drive) }\end{array}$ \\
\hline $\begin{array}{l}\text { Maximum combrusion } \\
\text { peak temperature }{ }^{\circ} \mathrm{C}\end{array}$ & 510 & 530 & 460 & 550 \\
\hline $\begin{array}{l}\text { Combusion front vetacity } \\
(\mathrm{m} / \mathrm{h})^{\dagger}\end{array}$ & 0.067 & 0.072 & 0.02 & 0.11 \\
\hline $\begin{array}{l}\text { Produced gas composiuion } \\
\text { (\%) average (maximum) } \\
\text { CO. } \\
\text { Co } \\
\text { o. }\end{array}$ & $\begin{array}{c}7 \quad(10) \\
1.55(2.2) \\
8(9.8)\end{array}$ & $\begin{array}{c}5.75(8) \\
1.5(2) \\
11.45(11.8)\end{array}$ & $\begin{array}{c}4.4(6.8) \\
1.5(2) \\
11.5(13) \\
\end{array}$ & $\begin{array}{l}44(65) \\
8.5(12) \\
33(50) \\
\end{array}$ \\
\hline $\begin{array}{l}\text { Alomic H/C ratio } \\
\text { stabilised period }\end{array}$ & $\begin{array}{c}1.3 \\
-\end{array}$ & 1.14 & 4,0 & 4.7 \\
\hline $\begin{array}{l}\text { Oxygen utisation ( } \% \text { ) } \\
\text { overall }\end{array}$ & 61.5 & 50 & 46 & 71 \\
\hline $\begin{array}{l}\text { Fuel constumption } \\
\mathrm{kg} / \mathrm{m}^{3} \text {, overall } \\
\% \text { OOIP. overall }\end{array}$ & $\begin{array}{l}15.4 \\
3.5\end{array}$ & $\begin{array}{r}13 \\
3.7 \\
\end{array}$ & $\begin{array}{l}16.2 \\
4.4 \\
\end{array}$ & $\begin{array}{l}14.1 \\
4.5 \\
\end{array}$ \\
\hline $\begin{array}{l}\text { Ait to futl ratio }\left(\mathrm{m}^{3} / \mathrm{kg}\right) \\
\text { overall }\end{array}$ & 12.1 & 9.6 & $1+.5$ & 22.6 \\
\hline $\begin{array}{l}\text { Air to oil ratio }\left(\mathrm{m}^{3} / \mathrm{m}^{3}\right) \\
\text { overall }\end{array}$ & $1+36$ & 1573 & 1709 & 3323 \\
\hline Oil recoven: \% OOIP & 67 & 51 & 55 & +6 \\
\hline Water producuon, $\% S_{w n}$ & 52 & 62 & 47 & 58 \\
\hline
\end{tabular}

+ excluding period of falling $\mathrm{CO}_{2}$ concentration

The atomic $H / C$ ratio values calculated from the combustion gas analyses are in the low range for the two air tests using line drive $(\mathrm{H} / \mathrm{C}=2.0$ for Forties crude oil), but much higher values occurred for both the air-pattern drive and the oxygen-line drive tests. For the latter two cases, $\mathrm{H} / \mathrm{C}=4.0$ and 4.2 , respectively. These relatively high values imply that significant low temperature oxidation (LTO) occurred during the tests. Relatively low oxygen utilisation was achieved during all of the tests, particularly with pattern drive, although it was substantially increased, up to $71 \%$, in the oxygen test. The relatively high levels of oxygen in the produced gases are also of concern, reflecting the generally low $\mathrm{CO}_{2}$ levels achieved. Some of these important fuel-related factors will be discussed in more detail later in the paper. Discussion will now be focussed on the detailed combustion temperature contours, relating to sweep efficiency and oil production. These results provide basic insight into the overall stability and propagation of the light oil in situ combustion process and its potential for economic productivity.

\section{Temperature Profiles}

\section{Ignition State}

Figure 2a shows a typical temperature distribution in the sandpack, for Run 1 at the horizontal midplane, five minutes after ignition. The vertical temperature contours below this are at the inlet face of the sandpack, and illustrate the extent of combustion occurring during the initial start-up period. Figure $2 b$ (air injection, line drive) shows a well-established high temperature combustion zone $\left(500-600^{\circ} \mathrm{C}\right)$ extending across the middle third of the sandpack, and also a broader combustion zone $\left(400-500^{\circ} \mathrm{C}\right)$ covering almost one-half of the inlet face. The situation is similar in Figure 2c for Run 2, at a slightly later time, in which the $\mathrm{S}_{\mathrm{oi}}$ was lower at $50 \%$. The highest temperature zone $\left(500-600^{\circ} \mathrm{C}\right)$ is more displaced, either side of the central region of the sandpack. Figure $2 d$ shows the post-ignition state for the pattern drive of Run 3. Here, the highest temperature zone $\left(400-500^{\circ} \mathrm{C}\right)$ exhibits a quite different overall contour, residing mainly in the bottom half of the sandpack, covering about onethird of the inlet face. Run 4, using oxygen, has clearly established a good initial burn condition, as shown in Figure 2e. This is not too different from the air test in Run 1.

Overall, the initial combustion state for the four light oil in situ combustion tests is remarkably good in view of the relatively low initial oil saturations and correspondingly high water saturations. The use of oxygen injection does not appear to create any superior effect. 


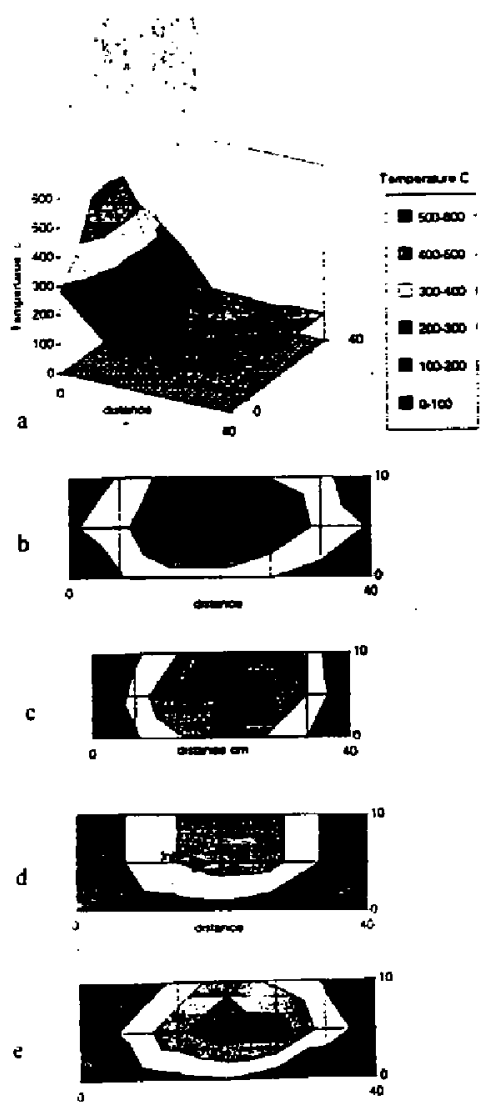

Figure 2

Temperature Profiles:

Horizontal mid-plane: (a) Run 2 ( $+5 \mathrm{~min}$ ); Vertical sections at inlet of sandpack: (b) Run 1 (+5 min); (c) Run 2 (+20 min); (d) Run 3 (+10 min); (e) Run 4 (+10 min)

Note: The vertical profiles shown need to be reversed, vertically)

\section{Horizontal Temperature Profiles}

Figure 3a shows the sequence of temperature contours obtained during Run 1 at the horizontal mid-plane position. At $t=15 \mathrm{~min}$, the combustion front is well-established across the inlet region of the sandpack, with the steam-gas zone (100-200 C) extending uniformly to one-third the distance along the cell. After a further 55 minutes of combustion time $(t=70 \mathrm{~min})$ the very high temperature zone has disappeared, and is replaced by an expanded combustion zone $\left(300-400^{\circ} \mathrm{C}\right)$. The leading edge of this combustion front has reached almost one-third of the distance through the sandpack, with the steam-gas front having now displaced through to two-thirds the distance. At $t$ $=130 \mathrm{~min}$, the expanded combustion zone (300$400^{\circ} \mathrm{C}$ ) has moved into the main reservoir body, with the steam-gas region now having extended up to the cell exit.
Figure $3 \mathrm{~b}$ shows the temperature contour sequence for Run 2, occurring at the TOP, MIDDLE and BOTTOM horizontal planes of the sandpack.

At $\mathrm{t}=85$ minutes (Fig $3 \mathrm{~b}$ ) the combustion front has developed fairly uniformly in the central and top regions of the sandpack. However, the main combustion zone $\left(400-500^{\circ} \mathrm{C}\right)$ in the bottom region of the sandpack is displaced about the central axis. Clearly, the high temperature zone $\left(300-400^{\circ} \mathrm{C}\right)$ and also the steam-gas front $\left(100-200^{\circ} \mathrm{C}\right)$ are more advanced in the top part of the sandpack. This indicates a level of gas override, but which nevertheless appears to be controlled. At the later time of $t=145 \mathrm{~min}$ (Fig 3c), combustion is most vigorous in the central and top regions of the sandpack, but now exhibits a more asymmetric condition. There is virtually a 100 per cent sweep by the steam-gas front, reinforced by a strong thermal front $\left(200-300^{\circ} \mathrm{C}\right)$ in the middle and bottom layers of the sandpack.

For a light oil, the strong distillation effect due to the high sweep efficiency of the steam-gas front should augur well for high oil recovery. On the other hand, it will have a negative effect regarding residual fuel for the process.

The horizontal temperature profiles at the midplane for Run 3 (pattern drive) and Run 4 (line drive with oxygen injection) are shown in Figure 4. By comparison also with Figure 3, it is apparent that the combustion condition in Run 3 is very much less vigorous, judging by the extent of the high temperature region. especially at the later times, $t=85$ and $160 \mathrm{~min}$. The horizontal sweep of the steam-gas zone in Run 3 is also less advanced in the bottom region of the sandpack. The oxygen test in Run 4 (Fig 4b), in contrast, develops a very vigorous combustion region $(t=75$ $\min$ ) but the rate of advance of the combustion front, defined by the 300 to $400^{\circ}$ contour, is reduced during the next 25 minutes. 

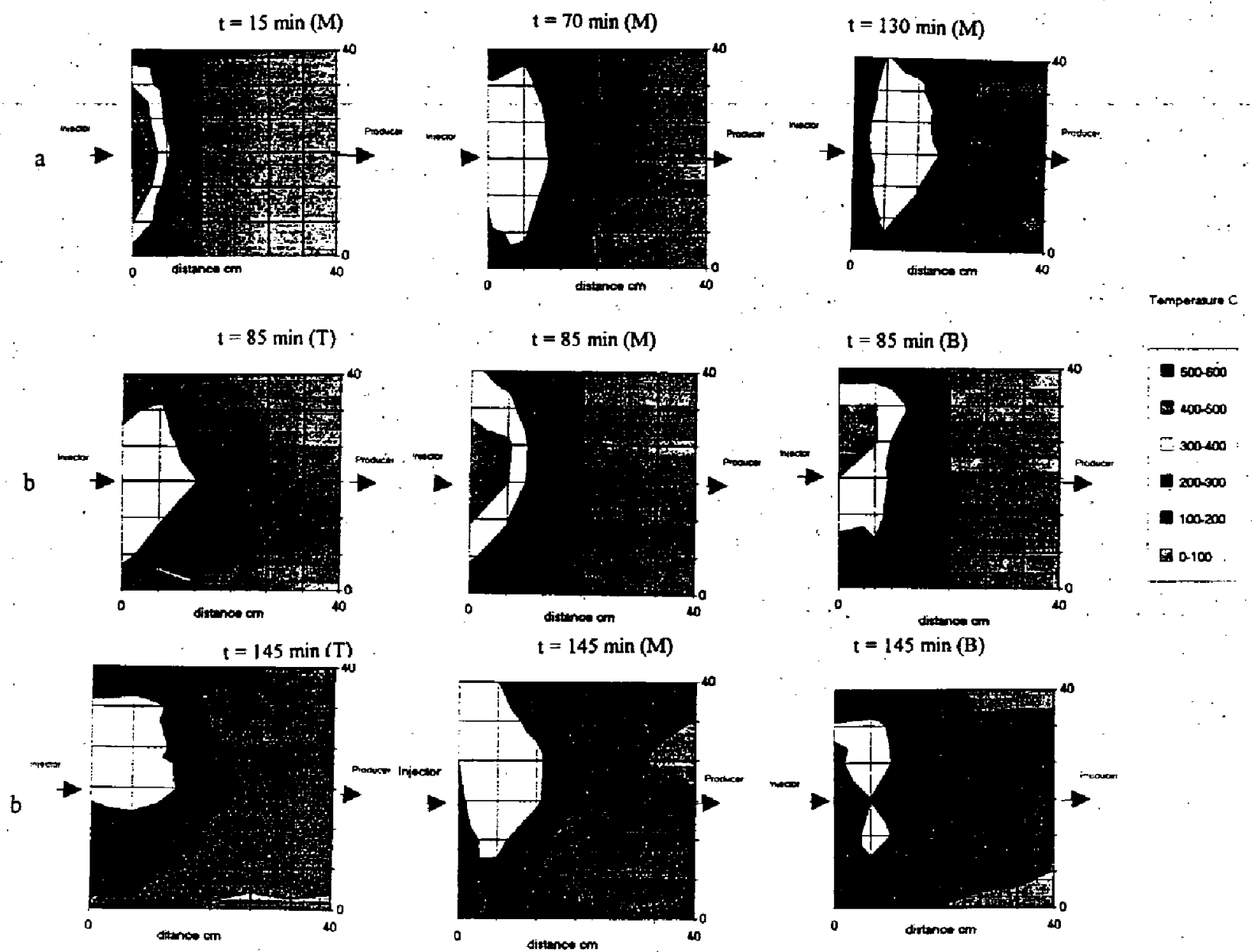

Figure 3

Temperature Profiles at TOP (T), MIDDLE (M) and BOTTOM (B) Horizontal Planes:

(a) Run 1; (b) Run 2 


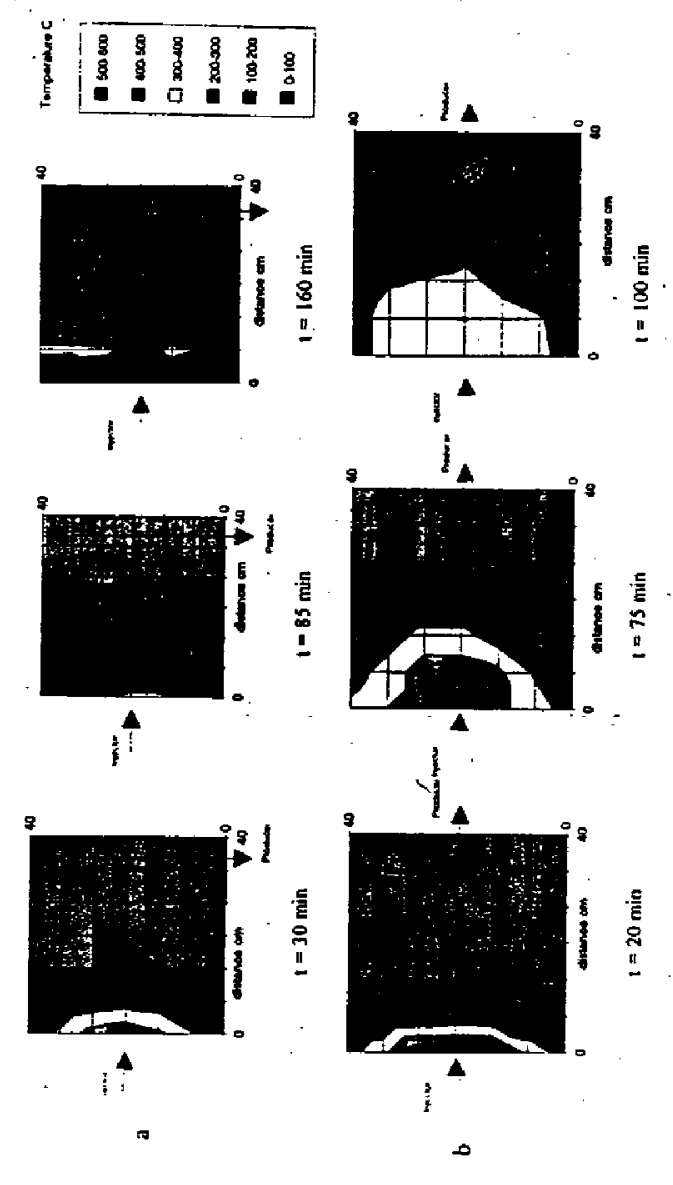

Figure 4

Temperature Profiles at Horizontal Mid-Plane: (a) Run 3; (b) Run 4

\section{Vertical Temperature Profiles and Combustion Front Stability}

One of the major concerns with any gas injection recovery process, in this case air (oxygen) injection, is the tendency for gravity gas override of the frontal displacement to occur, since this will ultimately lead to early gas breakthrough. The vertical temperature profiles for all four runs are shown in Figure 5 . These vertical profiles provide a useful indication of the stability of the combustion front and hence any development of gas override, i.e. tendency for the combustion front to follow an overriding oxygen path and consequently burn only in the upper sections of the reservoir.

Figure 5a (Run 1) shows that the leading edge of the high temperature zone, at $t=70 \mathrm{~min}$, has stabilised to an almost vertical condition over the bottom and middle regions, with a tilted profile in the top third of the sandpack This gravity gas override effect is responsible for the leading position of the steam-gas zone downstream. At $t=$
$130 \mathrm{~min}$, however, the combustion zone has expanded in size and now exhibits a vertical leading edge profile in the top half of the sandpack with a trailing profile in the bottom half. Clearly, the combustion zone $\left(300-400^{\circ} \mathrm{C}\right)$ is much more stable than previously. Interestingly, there appears to be some counterbalancing measure acting on the steam-gas front. This effect may be due to the influence of the horizontal producer well, creating a gravity-assisted flow downwards towards the well.

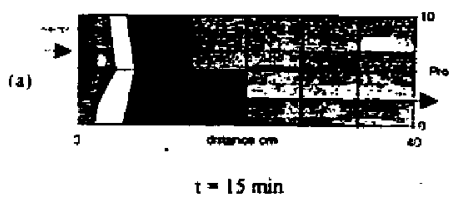

(c)

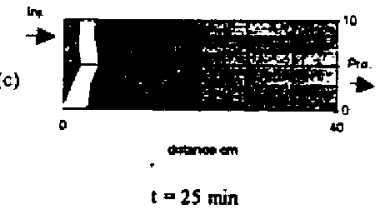

(a)
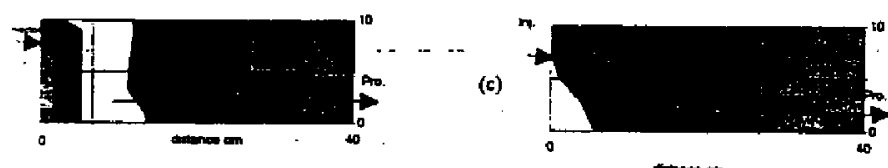

$t=70 \min$

(a)

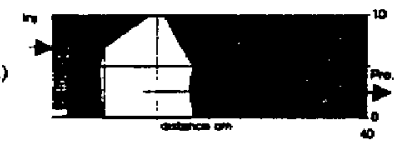

$t=130 \min$

(b)

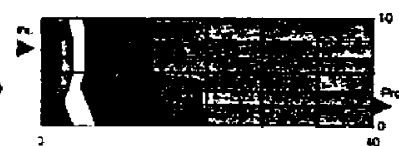

$t=85 \min$

(c)

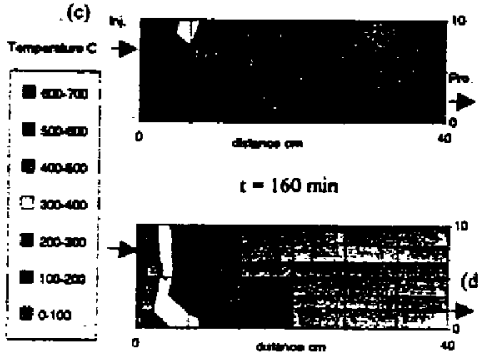

$t=30 \mathrm{~min}$

(b)

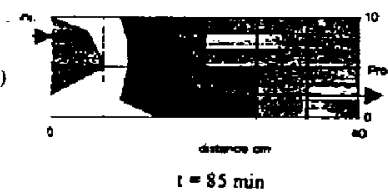

(b)

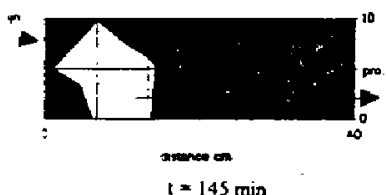

(d)

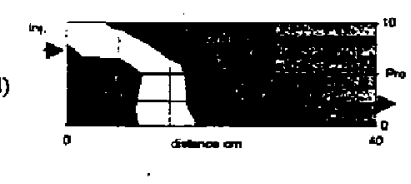

$\mathrm{t}=75 \mathrm{~min}$

(d)

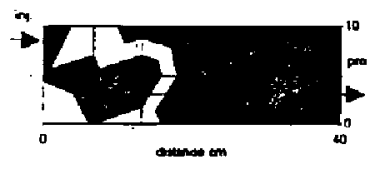

Figure 5

Temperature Profiles along Vertical Mid-Plane:

(a) Run 1; (b) Run 2; (c) Run 3; (d) Run 4

(Note: The profiles shown need to be reversed, vertically)

After 85 minutes, the leading high temperature zone $\left(300-400^{\circ} \mathrm{C}\right.$ ) in Run 2 (Fig 5 b) has advanced to a similar position to that in Run 1 , at $t=70$ min. Although the initial oil saturation is lower in Run $2\left(\mathrm{~S}_{\mathrm{oi}}=50 \%\right)$, there is still a substantial high temperature region $\left(400-500^{\circ} \mathrm{C}\right)$ extending out from the inlet end. mainly in the lower half of the sandpack. At $t=145 \mathrm{~min}$, the combustion zone $\left(300-400^{\circ} \mathrm{C}\right)$ is similar in overall extent to that in 
Run 1, with a basically stable profile. However, the combustion front is less advanced. probably due to lower fuel availability resulting from the lower initial $\mathrm{S}_{\mathrm{oi}}$.

The pattern drive arrangement used in Run 3 (Fig 5c) produces a distinctly different combustion profile compared to the line drive experiments. Although the combustion front temperature profile at $\mathbf{t}=\mathbf{2 5} \mathrm{min}$ is very similar to Run 1 , thereafter, at $t=85 \mathrm{~min}$, the combustion zone $\left(300-400^{\circ} \mathrm{C}\right)$ is greatly reduced in size and is confined to the top half of the sandpack. Gas override can be clearly seen at this stage. However, at $t=160 \mathrm{~min}$, the combustion zone $\left(300-400^{\circ} \mathrm{C}\right)$ has further reduced considerably in size, and has also moved to the bottom of the sandpack. The leading edge of the high temperature front $\left(200-300^{\circ} \mathrm{C}\right)$ appears moderately stable, but there is nevertheless significant gas override occurring in the top of the sandpack.

A very vigorous combustion zone $\left(400-600^{\circ} \mathrm{C}\right)$ develops throughout the combustion period for Run 4 (Fig 5d), aided by oxygen injection. The high temperature region exhibits a more complex shape at $\mathrm{t}=100 \mathrm{mins}$, propagating mainly in the top regions of the sandpack. Gas gravity override is occurring, but since the extent of this is reduced compared to $t=75 \mathrm{~min}$, some controlling factor is now influencing the process. It is possible that an increasing 'draw-down' effect occurs nearer the producing end of the horizontal well.

\section{Produced Gas ( $\mathrm{CO}_{2}$, Apparent $\mathrm{H} / \mathrm{C}$, \% Oxygen Utilisation)}

During in situ combustion, the combustion intensity is measured partly by the combustion peak temperature, but also the level of $\mathrm{CO}_{2}$ produced in the combustion gases. The $\mathrm{CO}_{2}$ values for Run 1 in Figure 6 are typical of the overall trend observed. Initially an increasing level, up to the highest value $(10 \%)$, then stabilising at a reduced level $(8.5 \%)$ and, in the final period, gradually reducing with combustion time. The declining phase, below a $\mathrm{CO}_{2}$ concentration of about $8 \%$, is due to a reduction of the combustion intensity, resulting in lower combustion temperature and diminished size of the combustion region.

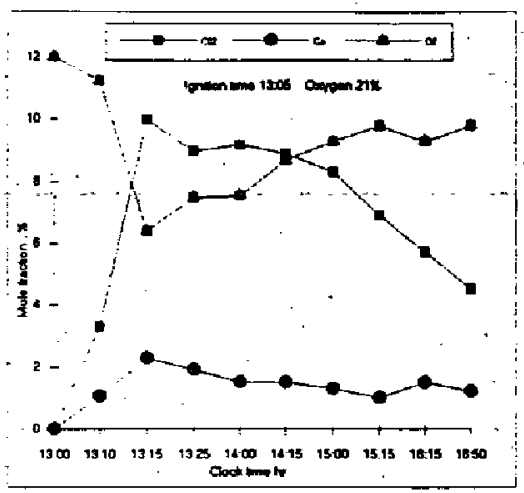

Figure 6

Produced Gas Composition, Run 1

In Table 2, it can be seen that low $\mathrm{CO}_{2}$ levels were achieved in each of the three air tests, due either to lack of fuel, or difficulty of combustion. The $\mathrm{CO}_{2}$ produced in the oxygen test (Run 4) is at a much higher. level (up to a maximum of $65 \%$ ), albeit at nearly twice the oxygen flux of the air tests.

Apparent $\mathrm{H} / \mathrm{C}$ ratios are low for Runs $\mathrm{l}$ and 2, at 1.3 and 1.14 , respectively, indicating little LTO effect ( $\mathrm{H} / \mathrm{C}=2.0$ for Forties crude), even though produced oxygen levels are high. Figure 7 shows the trend of $\mathrm{H} / \mathrm{C}$ during Run 2. The much higher $\mathrm{H} / \mathrm{C}$ values for Runs 3 and 4 (respectively, 4.0 and 4.2 ) indicate that significant LTO reaction probably occurred in these tests.

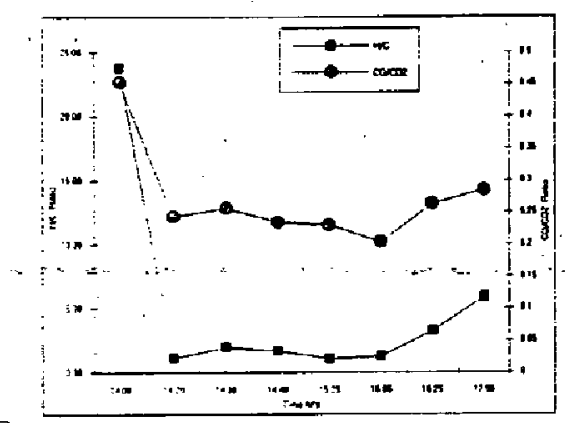

Figure 7

Apparent $\mathrm{H} / \mathrm{C}$ and $\mathrm{CO} / \mathrm{CO}_{2}$, Run 2

The dominant factor governing the sustainability of in situ combustion in a light oil reservoir is the amount of fuel available for combustion. Table 2 shows that fuel consumption values are relatively low for the light oil (as expected), varying from 3.5 to $4.5 \%$ OOIP. This is about one-third the level observed for heavy oil in situ combustion. Generaily, the early combustion state in all tests is good, and, with the exception of Run 3 (pattern drive), the combustion front velocities (front propagation) are at reasonable levels for the oxygen fluxes used, ranging from 0.067 to 0.11 $\mathrm{m} / \mathrm{h}$. Diminishing combustion intensity and front propagation, during the falling $\mathrm{CO}_{2}$ concentration period later in the tests, must therefore have been 
strongly affected by the degree of vaporisation occurring downstream of the combustion front. In view of the high initial water saturations $\left(S_{w i}=35\right.$ and $45 \%$ ) and the extent of the steam-gas front development $\left(100-200^{\circ} \mathrm{C}\right.$ temperature contour in Figs 3 and 4), the residual heavy end fraction of the crude left to be thermally cracked to fuel in the process will be reduced below the initial, already limiting, reservoir value.

In an actual light oil reservoir, the pressure may be high enough to sustain a second fuel mechanism. i.e. auto-ignition, as proposed by Yannimaras $e t$ al. [2] At higher pressure, vaporisation will be suppressed, creating a higher residuel oil availability for fuel formation. The success of light oil in situ combustion, or air injection process, in waterflooded reservoirs will require further understanding of the fuel formation-fuel combustion mechanisms, as well as the interplay between combustion front propagation and steamgas front advance. The results have demonstrated that the steam front-combustion gas zone during dry in situ combustion can achieve virtually 100 per cent sweep of the downstream oil.

\section{Oit Recovery}

The cumulative oil recovery (Fig. 8) increases continuously with combustion time, whereas the production rate is non-uniform. This trend occurred in all of the tests. Significantly, there is some measure of correspondence, albeit complex, between the rate of oil and water production. especially for Run 2. This suggests that the advance of the steam-gas region has a very significant effect on oil displacement.

Prior to ignition, when only nitrogen is flowing through the sandpack, some oil is produced. This initial oil production was highest in Run 1 at about $23 \%$ OOIP, and lowest in Run 4 at $11 \%$ OOIP, for which the total gas flux was also the lowest. The oil recoveries in Table 2 could be adjusted to take account of this initial oil production, but the trend between tests would remain the same. For the same test conditions, the oil recovery of $67 \%$ OOIP achieved by line drive (Run 1) is superior to that obtained by pattern drive (Run 2), which was $55 \%$ OOIP. Oil recovery is also significantly influenced by the residual waterflood state and hence residual oil saturation. Increasing the initial water saturation to $S_{w i}=45 \%$ in Run 2 results in a lower oil recovery of $51 \%$ OOIP compared to $67 \%$ OOIP in Run 1, for which $\mathrm{S}_{\mathrm{wi}}=35 \%$. The lowest oil recovery at $46 \%$ OOIP was achieved in Run 4 . using oxygen. This is mainly the effect of increased fuel consumption, being nearly one-third higher than in the air tests. The much higher airto-oil ratio for Run 4 , at $3323 \mathrm{~m}^{3} / \mathrm{m}^{3}$, reflects no economic advantage for using oxygen, although the amount of gas to be compressed will, of course, be only one-fifth this figure.

We have given water production values as a percentage of the initial water in place $\left(\% \mathrm{~S}_{\mathrm{wi}}\right)$ in Table 2. The trend is essentially what would be expected, in that Run 2, with $S_{w i}=45 \%$, is highest at $62 \%$ compared to $52 \%$ for Run 1, with $\mathrm{S}_{\mathrm{wh}}=$ $35 \%$. Run 4 is similar to Run 2 for the same $S_{w i}$. Water production in Run 3 (pattern drive) was, however, delayed considerably by more than two hours after ignition, compared to the other tests. This reflects the water-banking effect in the downstream condensation zone, but also the more advanced transport-displacement of the vaporised light oil moving ahead of the water zone. This behaviour is minimised with the line drive horizontal well configuration, since mobile oil and gases are drawn into the well earlier. Oil and gas flow into the horizontal well is complex and further study is required to understand the detailed multiphase flow behaviour near the well bore, and also its horizontal flow.

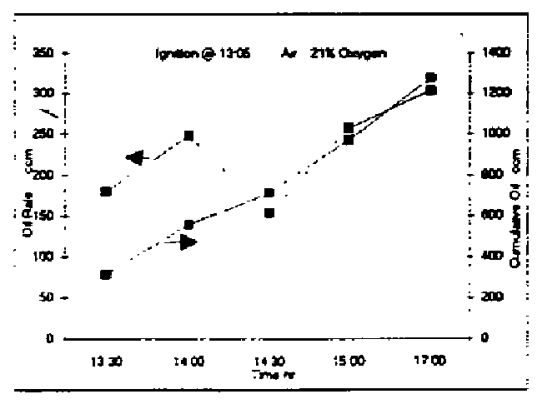

Figure 8

Oil Production, Run 1

\section{CONCLUSIONS}

$1 \quad$ Preliminary 3D tests carried out to physically simulate light oil in situ combustion. under waterflooded conditions. have shown that. when a horizontal producer well in line drive is used, high combustion zone temperatures are sustained at reasonably high combustion front velocities. This type of well configuration also confers a good measure of stability on the combustion front propagation. so that any tendency towards gas override is controlled. particularly further downstream towards the producing end of the cell. 
The oil recovery achieved was significantly influenced by the water saturation in the sandpack initially, i.e. the residual oil saturation, and also convective gas drive displacement prior to ignition. However, the main trend was to higher oil recovery with line drive compared to pattern drive, up to $67 \%$ OOIP in total. Oxygen in situ combustion also gave lower oil recovery compared to the air tests.

3. $\mathrm{CO}_{2}$ levels in the produced gases were generally low during the air tests at around $10 \%$ or less. but were much higher in the oxygen test, averaging approximately $44 \%$. Oxygen utilisation never achieved high levels and was lowest for the pattern drive test at $46 \%$. Oxygen in the produced gas tended to increase throughout the tests, up to quite high levels. However, the apparent $\mathrm{H} / \mathrm{C}$ ratio remained at low values $(\mathrm{H} / \mathrm{C} \leq 1.3)$ during the air-line drive tests, but increased to $\mathrm{H} / \mathrm{C} \geq 4.4$ for both the oxygen and air pattern drive tests. indicating LTO reaction.

Under dry combustion conditions (present tests), the high water saturation present initially in the sandpack $\left(\mathrm{S}_{\mathrm{wi}}-35\right.$ to $\left.45 \%\right)$ led to the development of a substantial steam-gas drive, with a volumetric sweep approaching 100 per cent. The resulting light ends vaporisation is therefore very significant in the process, but it may also act to limit an already marginal fuel availability.

\section{REFERENCES}

1 Gregory A T, 'DTI's Improved Oil Recovery Strategy', Trans IChemE, 1994, 72 Part A, 137-143

2 Yannimaras D V, Sufi A H and Fassihi $M$ $R$, 'The Case for Air Injection into Deep, Light Oil Reservoirs', 6th European IOR Symposium, 1991, Stavanger, pp55-64

3 Hansel J G, Benning $M A$ and Fernbacher $J \mathrm{M}$, 'Oxygen Insitu Combustion for Oil Recovery: Combustion Tube Tests', J of Petroleum Technology, 1984, 1139-1144

4 Shahani G H and Hansel J G, 'Oxygen Fireflooding: Combustion Tube Tests with Light, Medium and Heavy Crude Oils', SPE Reservoir Engineering, Nov 1987, 583-590

5 Tzanco E T, Moore R G, Belgrave J D Mand Ursenbach M C, 'Laboratory Combustion Behaviour of Countess B Light Oil', Paper No. CIM/SPE 90-63, CIM/SPE International Technical Meeting, 1991, Calgary, pp63.1-63.16 Ben Rahil M, 'Numerical Simulation and Experiments of Insitu Combustion using Horizontal Wells', MPhil Thesis, University of Bath, 1995

\section{ACKNOWLEDGEMENT}

The authors are grateful to British Petroleum plc (Sunbury Research Centre) for supplying the Forties crude oil. M. Ben Rahil is grateful to the Arabian Gulf Oil Company for financial support during his period of research at Bath University.

\section{SYMBOLS}

$\begin{array}{ll}\text { EOR } & \begin{array}{l}\text { enhanced oil recovery } \\ \text { atomic hydrogen to carbon } \\ \text { ratio } \\ \text { improved oil recovery } \\ \text { million barrels of oil } \\ \text { equivalent }\end{array} \\ \text { IOR } & \begin{array}{l}\text { original oil-in-place } \\ \text { initial oil saturation in } \\ \text { sandpack, at waterflooded } \\ \text { condition (\%) }\end{array} \\ \text { OOIP } & \begin{array}{l}\text { initial water saturation in } \\ \text { sandpack, at waterflooded } \\ \mathrm{S}_{\mathrm{oi}}\end{array} \\ & \begin{array}{l}\text { condition (\%) } \\ \text { combustion time (minutes) }\end{array} \\ \mathrm{S}_{\mathrm{wi}} & \end{array}$

